\title{
Expression and activity of hydrogen sulfide generating enzymes in murine macrophages stimulated with lipopolysaccharide and interferon- $\gamma$
}

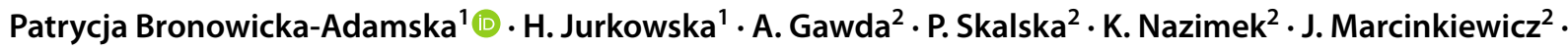 \\ Maria Wróbel ${ }^{1}$ (D)
}

Received: 19 November 2018 / Accepted: 27 February 2019 / Published online: 11 March 2019

(c) The Author(s) 2019

\begin{abstract}
Murine macrophages of the J774A.1 line are hydrogen sulphide-producing cells with the primary role of $\gamma$-cystathionase $(\mathrm{CTH})$ and secondary role of 3-mercaptopyruvate sulfurtransferase (limited by cysteine availability) and with a negligible role of cystathionine $\beta$-synthase (CBS) in $\mathrm{H}_{2} \mathrm{~S}$ generation. J774A.1 cells stimulation with lipopolysaccharide (LPS) or interferongamma (IFN $\gamma$ ) resulted in decreased $\mathrm{H}_{2} \mathrm{~S}$ levels after $24 \mathrm{~h}$ of incubation; however, they were restored to the control level after 48 h. Negligible CBS expression and activity in J774A.1 cells can result in homocysteine availability for CTH-catalyzed, $\mathrm{H}_{2} \mathrm{~S}$-generating reactions. This was supported by an increased CTH expression (IFN $\gamma, 24 \mathrm{~h}$ and $48 \mathrm{~h}$, and LPS, $48 \mathrm{~h}$ ) and activity (24 h, LPS) in the stimulated cells. The results confirm the suggested feedback regulation between CBS and CTH.
\end{abstract}

Keywords $\gamma$-Cystathionase $\cdot$ Hydrogen sulfide $\cdot$ Interferon $\cdot$ Lipopolysaccharide $\cdot$ Mouse macrophages

$\begin{array}{ll}\text { Abbreviations } \\ \text { CBS } & \text { Cystathionine } \beta \text {-synthase } \\ \text { CTH } & \gamma \text {-Cystathionase } \\ \text { HCys } & \text { Homocysteine } \\ \text { IFN } \gamma & \text { Interferon } \gamma \\ \text { LPS } & \text { Lipopolysaccharide } \\ \text { MPST } & \text { 3-Mercaptopyruvate sulfurtransferase } \\ \text { TST } & \text { Rhodanese }\end{array}$

\section{Introduction}

Methionine is metabolized to homocysteine (HCys) to produce cysteine, which is a substrate of two enzymes-cystathionine $\beta$-synthase (CBS) and $\gamma$-cystathionase $(\mathrm{CTH})$ involved in endogenous production of $\mathrm{H}_{2} \mathrm{~S}$ (Scheme 1) [1]. In cells with low CBS expression, $\mathrm{H}_{2} \mathrm{~S}$ can be alternatively generated by $\mathrm{CTH}$-catalyzed condensation reaction between

Maria Wróbel

mbwrobel@cyf-kr.edu.pl

1 Chair of Medical Biochemistry, Jagiellonian University Medical College, Kopernika 7 St., 31-034 Kraków, Poland

2 Department of Immunology, Jagiellonian University Medical College, Czysta 18, 31-121 Kraków, Poland cysteine and HCys or between two molecules of HCys (Scheme 1) [2].

Another endogenous source of $\mathrm{H}_{2} \mathrm{~S}$ is cysteine transamination by cysteine aminotransferase (CAT) and subsequent 3-mercaptopyruvate (3MP) conversion by 3-mercaptopyruvate sulfurtransferase (MPST) [3]. 3MP provides sulfur to the active-site cysteine residue of MPST to produce persulfide, which releases $\mathrm{H}_{2} \mathrm{~S}$ in the presence of thioredoxin (Trx), abundant in cells. Another physiological reducing disulfide is dihydrolipoic acid (DHLA), cofactor for mitochondrial $\alpha$-ketacid dehydrogenases. Trx and DHLA release $\mathrm{H}_{2} \mathrm{~S}$ from persulfide provided by $3 \mathrm{MP}$ at the active site of MPST [4]. The expression of CBS, CTH and MPST are tissue-specific.

Hydrogen sulfide $\left(\mathrm{H}_{2} \mathrm{~S}\right)$ plays an important role in inflammation [5] but there is no clear consensus as to its precise role in inflammatory signaling. Macrophages in general play important roles in the initiation and progression of many chronic inflammatory diseases. Li et al. [6] observed biphasic effects of $\mathrm{H}_{2} \mathrm{~S}$ on inflammatory signals in murine lipopolysaccharide (LPS)-treated macrophages, where low $\mathrm{H}_{2} \mathrm{~S}$ levels inhibited LPS-induced synthesis of $\mathrm{PGE}_{2}$, NO, IL-1 $\beta$, IL-6 and NF- $\mathrm{KB}$ activity, but higher NaHS concentrations promoted synthesis of pro-inflammatory mediators.

LPS- a potent activator of macrophages, and interferongamma (IFN $\gamma$ - — the principal macrophage-activating factor, 
Scheme 1 Hydrogen sulfide generation and effect on superoxide levels in cells with low CBS expression. DHLA dihydrolipoic acid, MPST 3-mercaptopyruvate sulfurtransferase, $\operatorname{Tr} x$ thioredoxin, $C B S$ cystathionine $\beta$-synthase, $C T H$

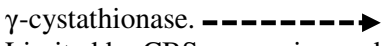
Limited by CBS expression and activity. ................ $\rightarrow$ Limited by cysteine availability

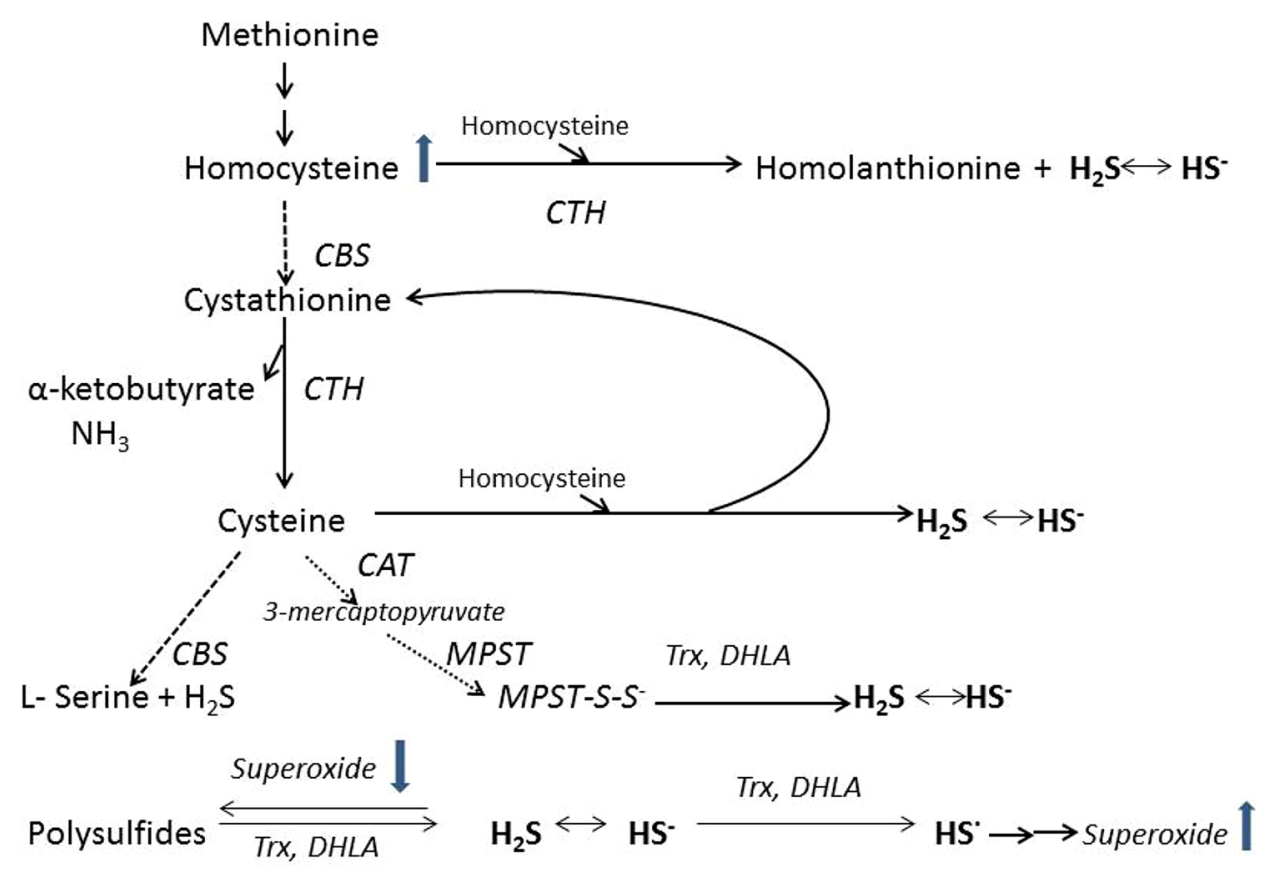

was used to stimulate murine macrophages of the J774A.1 cell line. $\mathrm{H}_{2} \mathrm{~S}$ measured by the zinc acetate-trapping method [7] was used to compare the $\mathrm{H}_{2} \mathrm{~S}$ level in the control, and LPS- and IFN $\gamma$-stimulated cells after 24 and $48 \mathrm{~h}$ of incubation. The expression and the activity of hydrogen sulfidegenerating enzymes, i.e. CBS, MPST, CTH, and TST, were investigated in J774A.1 cells. The results indicate an important role of CTH in the generation of hydrogen sulfide in J774A. 1 cells with low activity of the transsulfuration pathway catalyzed by the CBS/CTH enzymatic system. They also confirm a negative feedback regulation between CBS and CSE [8].

The studies presented in this paper were designed to determine the activity and expression of hydrogen sulfide generating enzymes, i.e.: cystathionine $\beta$-synthase (CBS), $\gamma$-cystathionase (CTH) and MPST in murine macrophages stimulated with LPS and IFN- $\gamma$.

\section{Materials and methods}

\section{Chemicals}

1-Fluoro-2,4-dinitrobenzene, bathophenanthrolinedisulfonic acid disodium salt, acetonitrile, pyridoxal phosphate (PLP), $\beta$-nicotinamide adenine dinucleotide reduced disodium salt hydrate (NADH), L-lactic dehydrogenase (LDH), 3-mercaptopyruvate acid sodium salt, D, L-dithiothreitol (DTT), $N$-ethylmaleimide (NEM), DLpropargylglycine (PPG), $\mathrm{NaH}_{2} \mathrm{PO}_{4} \cdot 2 \mathrm{H}_{2} \mathrm{O} \mathrm{Na} \mathrm{NO}_{3}$, chloroform, isopropanol, agarose, sodium hydrosulfide hydrate,
$\mathrm{NaCl}$, Folin-Ciocalteu's phenol reagent, $\mathrm{Fe}\left(\mathrm{NO}_{3}\right)_{3} \cdot 9 \mathrm{H}_{2} \mathrm{O}$, $\mathrm{Na}_{2} \mathrm{~S}_{2} \mathrm{O}_{3} \cdot 5 \mathrm{H}_{2} \mathrm{O}, \mathrm{Na}_{2} \mathrm{CO}_{3}$ and $N, N$-dimethyl- $p$-phenylenediamine sulfate salt (DMPPDA) were obtained from SigmaAldrich (St. Louis, MO, USA). Trifluoroacetic acid and 2-mercaptoethanol were purchased from Fluka Chemie GmbH (Buchs, Switzerland). Ethanol and 70\% perchloric acid $38 \%$ formaldehyde, $65 \% \mathrm{HNO}_{3}, 38 \% \mathrm{HCl}$, ammonia solution $25 \%$, sodium potassium tarate, copper sulphate pentahydrate $\left(\mathrm{CuSO}_{4} \cdot 5 \mathrm{H}_{2} \mathrm{O}\right)$ potassium dihydrogen phosphate $\left(\mathrm{KH}_{2} \mathrm{PO}_{4}\right)$, ferric chloride $\left(\mathrm{FeCl}_{3}\right),\left(\mathrm{Zn}\left(\mathrm{CH}_{3} \mathrm{COO}\right)_{2} \cdot 2 \mathrm{H}_{2} \mathrm{O}\right)$, and sodium hydroxide $(\mathrm{NaOH})$ were from Polskie Odczynniki Chemiczne S.A. (Gliwice, Poland). $N^{\varepsilon}$-methyllysine was obtained from Bachem (Bubendorf, Switzerland). DMEM/ high glucose (Lonza, Basel, Switzerland), fetal bovine serum and penicillin-streptomycin solution were purchased from Gibco Invitrogen, Life Technologies, (Grand Island, NY, USA). Trizol, ethidium bromide and EDTA-disodium salt dihydrate were obtained from Lab-Empire (Rzeszow, Poland). KCN was obtained from Merck (Darmstadt, Germany). Reverse transcriptase M-MuLV was obtained from Promega (Madison, WI, USA). Polymerase DNA Dream Taq $^{\mathrm{TM}}$, Gene Ruler 100 bp DNA Ladder, Oligo(dT)18 primer and dNTP mix were obtained from Abo (Gdańsk, Poland). All the chemicals were analytical grade and HPLC solvents were gradient grade. Water was deionized by passing through an EASY pure RF compact ultrapure water system. 


\section{Cell culture}

Mouse BALB/c monocyte macrophage of the J774A.1 cell line (ATCC, Manassas, VA, USA) were grown in DMEM medium supplemented with $10 \%$ FCS, and antibiotics (100 U/ml penicillin and $100 \mu \mathrm{g} / \mathrm{ml}$ streptomycin), in sterile, plastic culture flasks (BD Falcon, Franklin Lakes, NJ, USA), at $37^{\circ} \mathrm{C}$, in a humidified atmosphere containing $5 \%$ $\mathrm{CO}_{2}$. For experiments, the cells were cultured in DMEM medium supplemented with 5\% FCS and antibiotics (as above) at $37{ }^{\circ} \mathrm{C}$, in a humidified atmosphere containing $5 \% \mathrm{CO}_{2}$, either on sterile, plastic Petri dishes $(100 \mathrm{~mm}$ in diameter) or on sterile, plastic, 24-well, flat-bottom plates. J774A. 1 cells were stimulated for $24 \mathrm{~h}$ and $48 \mathrm{~h}$ with LPS $\left(100 \mathrm{ng} / 5 \times 10^{5}\right.$ cells $/ \mathrm{ml}$; Sigma Aldrich, St. Louis, MO, USA) or with recombinant IFN $\gamma\left(100 \mathrm{U} / 5 \times 10^{5}\right.$ cells $/ \mathrm{ml}$; PeproTech, London, UK). When necessary, after a certain time of stimulation, dry cell pellets were frozen and stored at $-80{ }^{\circ} \mathrm{C}$ prior to RNA isolation.

\section{The release of TNFa and IL-6 by J774A.1 cells stimulated with IFNy and LPS}

J774A. 1 cells $\left(5 \times 10^{5}\right.$ cells $/ \mathrm{ml} /$ well $)$, cultured on sterile, plastic, 24-well, flat-bottom plates at $37^{\circ} \mathrm{C}$ and $5 \% \mathrm{CO}_{2}$, were stimulated with either LPS $(100 \mathrm{ng} / \mathrm{ml})$ or IFN $\gamma$ $(100 \mathrm{U} / \mathrm{ml})$, as described above. After $24 \mathrm{~h}$, cell-free culture supernatants were collected, frozen and stored at $-20{ }^{\circ} \mathrm{C}$ for further detection of cytokine concentrations. TNF $\alpha$ and IL-6 concentrations were measured in ELISA according to procedures delivered by manufacturers with ELISA kits, i.e. mouse TNF $\alpha$ ELISA Ready-SET-Go! (Bioscience, Inc., San Diego, CA, USA) and mouse IL-6 BD OptEIA ${ }^{\text {TM }}$ Set (BD Biosciences, San Diego, CA, USA).
Expression of MPST, CTH, CBS, and rhodanese (TST) in J774A.1 cells

\section{Isolation of total RNA}

Total RNA was extracted with Trizol reagent (Lab-Empire, Poland) following the manufacturer's instructions and RNA quantity and integrity were verified by agarose gel electrophoresis. Isolated RNA was stored at $-80^{\circ} \mathrm{C}$ and was used for RT-PCR.

\section{Reverse transcription of RNA}

Total RNA ( $3 \mu \mathrm{g}$ ) was reversely transcribed with $1 \mu \mathrm{l}$ of GoScript $^{\mathrm{TM}}$ Reverse Transcriptase (160 U/ $\mu \mathrm{l}$; Promega Corporation), $4 \mu \mathrm{l}$ of GoScript ${ }^{\mathrm{TM}} 5 \times$ reaction buffer (Promega Corporation), $3 \mu \mathrm{l}$ of $\mathrm{MgCl}_{2}, 1 \mu \mathrm{l}$ of RNase Inhibitor (20 U/ $\mu \mathrm{l}$; Thermo Scientific), $1 \mu \mathrm{l}$ of dNTP mix (10 mM; Thermo Scientific), and $1 \mu$ of GoScript ${ }^{\mathrm{TM}}$ Reverse Transcriptase (160 U/ $\mu \mathrm{l}$; Promega Corporation) in $20 \mu \mathrm{l}$ of final volume of reaction mixture. RNA was mixed with Oligo $d(T)$ primer and was heated for $5 \mathrm{~min}$ at $70^{\circ} \mathrm{C}$. Then, samples were incubated in the reaction mixture for $5 \mathrm{~min}$ at $25^{\circ} \mathrm{C}, 60 \mathrm{~min}$ at $42{ }^{\circ} \mathrm{C}$ and $15 \mathrm{~min}$ at $70{ }^{\circ} \mathrm{C}$.

\section{Polymerase chain reaction (PCR)}

PCR was performed using $2 \mu \mathrm{l}$ of cDNA, $0.2 \mu \mathrm{M}$ of each primer, $0.04 \mathrm{U} / \mu \mathrm{l}$ of DNA polymerase (Thermo Scientific) in $10 \mathrm{mM}$ buffer Tris- $\mathrm{HCl} \mathrm{pH} 8.8$ (supplemented with $1.5 \mathrm{mM}$ $\mathrm{MgCl}_{2}, 50 \mathrm{mM} \mathrm{KCl}, 0.1 \%$ Triton X-100), $0.2 \mathrm{mM}$ of dNTP mix (Thermo Scientific) and $\mathrm{H}_{2} \mathrm{O}-$ DEPC in total reaction volume of $25 \mu \mathrm{l}$. The primer sequences are described in Table 1.

For CTH, after an initial 5 min denaturation at $94{ }^{\circ} \mathrm{C}$, amplification was performed under the following conditions: $94{ }^{\circ} \mathrm{C}$ for $30 \mathrm{~s}, 57^{\circ} \mathrm{C}$ for $30 \mathrm{~s}$, and $72{ }^{\circ} \mathrm{C}$ for $2 \mathrm{~min}$ for 35 cycles, with a final incubation at $72{ }^{\circ} \mathrm{C}$ for $8 \mathrm{~min}$.

For CBS, after an initial 5 min denaturation at $94{ }^{\circ} \mathrm{C}$, amplification was performed under the following conditions:
Table 1 Primer sequences used for RT-PCR

\begin{tabular}{lll}
\hline Genes & Forward $\left(\right.$ F) and reverse $(\mathrm{R})$ primers $\left(5^{\prime}-3^{\prime}\right)$ & RT-PCR product size $(\mathrm{bp})$ \\
\hline CTH & F: CATGGATGAAGTGTATGGAGGC & $445[10]$ \\
& R: CGGCAGCAGAGGTAACAATCG & \\
CB & F: TGCGGAACTACATGTCCAAG & $307[11]$ \\
MPST & R: TTGCAGACTTCGTCTGATGG & \\
& F: GATCCCTCTTTCATCAAG & $400[12]$ \\
TST & R: CATGTACC ACTCTACCCA & 149 (NCBI data base) \\
& F: AGGCACGCAAAGAGTACCAG & \\
$\beta$-Actin & R: GTTGCTTATGCCCAGGTTGC & $513[9]$ \\
& F: ATGGTGGGAATGGGTCAGAAGGAC & \\
\hline
\end{tabular}


$94{ }^{\circ} \mathrm{C}$ for $30 \mathrm{~s}, 56{ }^{\circ} \mathrm{C}$ for $30 \mathrm{~s}$, and $72{ }^{\circ} \mathrm{C}$ for 2 min for 35 cycles, with a final incubation at $72{ }^{\circ} \mathrm{C}$ for $8 \mathrm{~min}$.

For MPST, after an initial 5 min denaturation at $94^{\circ} \mathrm{C}$, amplification was performed under the following conditions: $94{ }^{\circ} \mathrm{C}$ for $30 \mathrm{~s}, 54{ }^{\circ} \mathrm{C}$ for $30 \mathrm{~s}$, and $72{ }^{\circ} \mathrm{C}$ for $2 \mathrm{~min}$ for 30 cycles, with a final incubation at $72{ }^{\circ} \mathrm{C}$ for 8 min [9].

For TST, after an initial 5 min denaturation at $95^{\circ} \mathrm{C}$, amplification was performed under the following conditions: $95{ }^{\circ} \mathrm{C}$ for $30 \mathrm{~s}, 55^{\circ} \mathrm{C}$ for $30 \mathrm{~s}$, and $72{ }^{\circ} \mathrm{C}$ for 2 min for 34 cycles, with a final incubation at $72{ }^{\circ} \mathrm{C}$ for $8 \mathrm{~min}$.

For $\beta$-actin, after an initial 5 min denaturation at $94^{\circ} \mathrm{C}$, amplification was performed under the following conditions: $94{ }^{\circ} \mathrm{C}$ for $30 \mathrm{~s}, 55{ }^{\circ} \mathrm{C}$ for $35 \mathrm{~s}$, and $72{ }^{\circ} \mathrm{C}$ for $35 \mathrm{~s}$ for 32 cycles, with a final incubation at $72{ }^{\circ} \mathrm{C}$ for 8 min [10].

$\beta$-actin was used as an internal standard to normalize mRNA abundance. PCR products were analyzed by $2.0 \%$ agarose gel electrophoresis and imaged by UVI-KS 4000i/ ImagePC (Syngen Biotech, Poland).

\section{Detection of $\mathrm{H}_{2} \mathrm{~S}$}

$\mathrm{H}_{2} \mathrm{~S}$ produced during the incubation of the cell culture with $\mathrm{H}_{2} \mathrm{~S}$-releasing compounds was trapped as zinc sulfide in the zinc agarose layer according to [7]. The standard curve was linear at the concentration range of $0-250 \mu \mathrm{M}$ with a correlation coefficient of 0.994 .

\section{Enzymes assay}

\section{Cell homogenization}

Murine macrophage cells (line J774A.1) $\left(3.5-5 \times 10^{6}\right.$ cells/ pellet) were resuspended in $0.1 \mathrm{M}$ phosphate buffer $\mathrm{pH} 7.5$, in the proportion $1 \times 10^{6}$ cells $/ 0.07 \mathrm{ml}$ of the buffer, sonicated $3 \times 5$ s at $4{ }^{\circ} \mathrm{C}$ (Bandelin Sonoplus GM 70). After centrifugation at $1600 \times \mathrm{g}$ for $10 \mathrm{~min}$, the supernatant was used for the determination of protein concentration, sulfane sulfur levels and the activity of MPST, CTH and rhodanese. For reverse phase high performance liquid chromatography (RP-HPLC) analyses, the cells were resuspended in $0.1 \mathrm{ml}$ $10 \%$ PCA/1 mM BPDS. The sediment was separated by centrifugation at $1400 \times \mathrm{g}$ for $10 \mathrm{~min}$, and the supernatant was stored at $-80^{\circ} \mathrm{C}$ until analysis.

\section{MPST activity}

The MPST activity was assayed according to the method of Valentine and Frankelfeld 1974 [13] with some modification as described by Wróbel et al. [14] and Bronowicka-Adamska et al. [15]. The enzyme activity was expressed as nmoles of pyruvate produced during $1 \mathrm{~min}$ incubation at $37^{\circ} \mathrm{C} / 1 \mathrm{mg}$ of protein.

\section{CTH activity}

The cystathionase activity was determined by Matsuo and Greenberg [16] with modifications described by Czubak et al. [17]. The difference between the initial value of absorbance (before adding LDH) and the lowest value (after adding LDH) corresponded to the amount of alpha-ketobutyrate formed in the course of the cystathionase reaction. The cystathionase activity was expressed as nmoles of $\alpha$-ketobutyrate formed during 1 min incubation at $37^{\circ} \mathrm{C} / 1 \mathrm{mg}$ of protein.

\section{CBS activity}

The activity of CBS was examined in cell homogenates in the presence of DL-homoserine as a substrate after $15 \mathrm{~min}$ incubation at $37{ }^{\circ} \mathrm{C}$ according to the description by Bronowicka-Adamska et al. [18]. The level of cystathionine was determined using the HPLC method described by Bronowicka-Adamska et al. [19]. The CBS activity was expressed as pmoles of cystathionine formed during $1 \mathrm{~min}$ incubation at $37^{\circ} \mathrm{C} / 1 \mathrm{mg}$ of protein.

\section{Sulfane sulfur level}

Sulfane sulfur was determined by the method of Wood [20] following the procedure described by Bronowicka-Adamska et al. [15]. The method is based on cold cyanolysis and colorimetric detection of ferric thiocyanate complex ion. The sulfane sulfur level was expressed as nmoles of $\mathrm{SCN}^{-}$produced/1 $\mathrm{mg}$ of protein.

\section{Protein level}

Protein concentration was determined by the method described by Lowry et al. [21] using crystalline bovine serum albumin as a standard.

\section{RP-HPLC (reverse phase high performance liquid chromatography)}

The levels of cystathionine in the incubation mixtures were determined using the RP-HPLC method Dominik et al. [22] with modifications [19].

\section{Statistical analysis}

All the results from at least three independent experiments, 15-25 individual determinations, were expressed as mean \pm SD. The significance of the differences between the controls and investigated samples were calculated using is a nonparametric Mann-Whitney U test $(\mathrm{p}<0.05)$. 
Table 2 The release of TNF $\alpha$ and IL- 6 by J774A.1 cells stimulated with IFN $\gamma$ or LPS

\begin{tabular}{llc}
\hline Cytokines & TNF $\alpha(\mathrm{pg} / \mathrm{ml})$ & IL-6 $(\mathrm{pg} / \mathrm{ml})$ \\
\hline IFN $\gamma$ & $209.3 \pm 8.5$ & $296.6 \pm 20.6$ \\
LPS & $10.46 \pm 2.11$ & $22.01 \pm 3.72$
\end{tabular}

The results represent three independent experiments. The macrophages of the J774A. 1 cell line $\left(5 \times 10^{5}\right.$ cells $/ \mathrm{ml} /$ well $)$ were stimulated with IFN $\gamma(100 \mathrm{U} / \mathrm{ml})$ or LPS $(100 \mathrm{ng} / \mathrm{ml})$ for $24 \mathrm{~h}$. TNF $\alpha$ and IL- 6 concentrations in culture supernatants were measured using the ELISA test

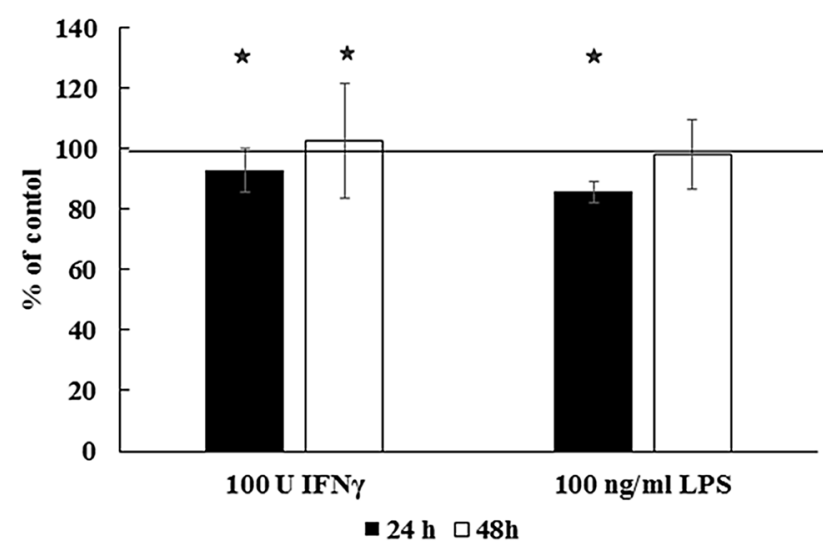

Fig. $1 \mathrm{H}_{2} \mathrm{~S}$ production in LPS and IFN $\gamma$-stimulated J774A.1 cells after $24 \mathrm{~h}$ and $48 \mathrm{~h}$ of stimulation. ${ }^{*} \mathrm{p}<0.05 \mathrm{LPS}$, IFN $\gamma$ versus the controls (Mann-Whitney $\mathrm{U}$ test). The control levels were $7.2 \pm 1.5 \mu \mathrm{M} \mathrm{H}_{2} \mathrm{~S} / \mathrm{h}$ for $24 \mathrm{~h}$ and $6.3 \pm 1.08 \mu \mathrm{M} \mathrm{H}_{2} \mathrm{~S} / \mathrm{h}$ for $48 \mathrm{~h}$

\section{Results}

\section{The release of TNFa and IL-6 by J774A.1 cells stimulated with IFNy or LPS}

After stimulation with both factors, macrophages released proinflammatory mediators. The effects of LPS stimulation was weaker than IFN $\gamma$ (Table 2).

\section{$\mathrm{H}_{2} \mathrm{~S}$ levels in control, and LPS and IFNY-stimulated J774A.1 cells}

The level of hydrogen sulphide was significantly lower after $24 \mathrm{~h}$ in case of both factors (Fig. 1). It was restored to the control levels after $48 \mathrm{~h}$ of incubation.
The expression of MPST, CTH, CBS and TST in murine macrophage cells (J774A.1 cells)

After $24 \mathrm{~h}$ incubation the control cells, not stimulated (Fig. 2a, line 1), express $\gamma$-cystathionase $(\mathrm{CTH})$ and MPST, two $\mathrm{H}_{2} \mathrm{~S}$-forming enzymes. Low TST expression and only trace expression of cystathionine $\beta$-synthase (CBS) was found. Similarly after 48 h (Fig. 2a, line 4) with the exception of higher expression of TST, as compare to $24 \mathrm{~h}$, and lower expression of CTH.

CBS expression did not change significantly in the LPSstimulated cells and it seemed even to drop in the IFN $\gamma$ stimulated cells (Fig. 2a, b). The expression of MPST significantly decreased during incubation with $100 \mathrm{U}$ IFN $\gamma$ and $100 \mathrm{ng} / \mathrm{ml}$ LPS. IFN $\gamma$, in turn, up-regulated CTH expression in J774A. 1 cells after both $24 \mathrm{~h}$ and $48 \mathrm{~h}$ stimulation, in comparison to the control cells (Fig. 2a, b).

\section{The activity of MPST, CTH, TST and the level of sulfane sulfur in J774A.1 cells after stimulation}

CBS activity in both the control and stimulated cells was undetectable. The activity of MPST (24 h) and rhodanese ( $24 \mathrm{~h}$ and $48 \mathrm{~h}$ ) was significantly decreased after incubation with IFN $\gamma$ and LPS after $48 \mathrm{~h}$, in comparison to the control cells (Table 3A, B). Significantly increased CTH activity was determined after $24 \mathrm{~h}$ and $48 \mathrm{~h}$ stimulation with LPS (Table 3A, B) but in case of IFN $\gamma$ it was below the detection limit after $24 \mathrm{~h}$ or significantly decreased after $48 \mathrm{~h}$, as compare to control values. A homeostasis of the level of sulfane sulfur was observed-it remains unchanged independently of the compound used and time of incubation (Table 3A, B).

\section{Discussion}

Hydrogen sulfide $\left(\mathrm{H}_{2} \mathrm{~S}\right)$ has been identified as a regulator of inflammatory responses [5].

The results have confirmed the expression of CTH and MPST in J774A.1 cells suggesting that macrophages are hydrogen sulphide producing cells. CBS seems to be of a low importance for $\mathrm{H}_{2} \mathrm{~S}$ formation in J774A. 1 cells.

Low CBS expression can result in HCys availability for $\mathrm{CTH}$-catalyzed $\mathrm{H}_{2} \mathrm{~S}$ generating reaction $[2,23]$ (Scheme 1). The IFN $\gamma$-stimulated production of NO was detected to result in a decrease in CBS activity [24] and it is attributed to a reduced rate of the transsulfuration pathway, CBS/CTH dependent, converting majority of HCys (Scheme 1). In the IFN $\gamma$-stimulated cells, an increased expression of CTH (Fig. 2a, b) after $24 \mathrm{~h}$ is correlated with a decreased - as compared to control-level of $\mathrm{H}_{2} \mathrm{~S}$. This can result from significantly decreased activity of CTH and TST observed after both $24 \mathrm{~h}$ and $48 \mathrm{~h}$ of incubation 
Fig. 2 RT-PCR analysis of MPST, CTH, CBS, TST in J774A. 1 cells. a One set of representative results is shown. $\beta$-Actin was used as the internal control. 1 Control $24 \mathrm{~h}, 2100 \mathrm{U}$ IFN $\gamma, 24 \mathrm{~h}, 3100 \mathrm{ng} / \mathrm{ml}$ LPS, $24 \mathrm{~h}, 4$ control, $48 \mathrm{~h}, 5100 \mathrm{U}$ IFN $\gamma, 48$ h, 6100 ng/ml LPS, $48 \mathrm{~h}$. b The relative expression level of MPST, CTH, CBS, TST in J774A. 1 cells. Densities of bands were normalized using $\beta$-actin, the mean of which was taken as equal to one. $* \mathrm{p}<0.05$ LPS, IFN $\gamma$ versus control (Mann-Whitney U test). ${ }^{\#}$ The density of CBS after $24 \mathrm{~h}$ was out of detection
Table 3 The activity of MPST, CTH, TST and the level of sulfane sulfur in J774A. 1 cells after $24 \mathrm{~h}(\mathrm{~A})$ and $48 \mathrm{~h}$ (B) of stimulation with LPS and IFN $\gamma$
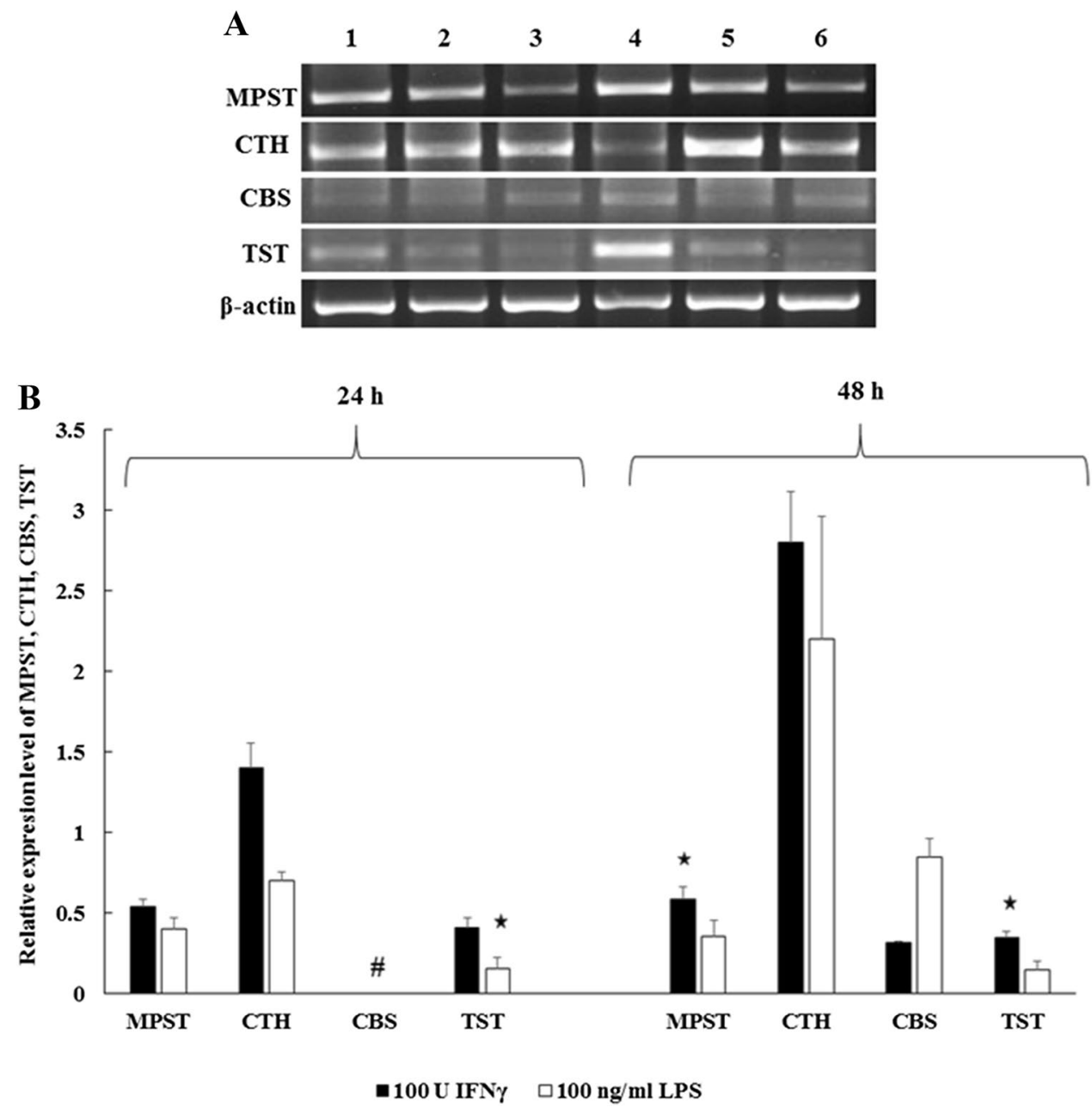

\begin{tabular}{llllc}
\hline J774A cells & MPST (nmol/mg'min) & CTH (nmol/mg/min) & TST (nmol/mg/min) & $\begin{array}{l}\text { Sulfane sul- } \\
\text { fur (nmol/ } \\
\text { mg) }\end{array}$ \\
\hline (A) & & & & \\
Control & $617 \pm 98$ & $1.46 \pm 0.67$ & $101 \pm 28$ & $158 \pm 36$ \\
IFN $\gamma 100 \mathrm{U}$ & $489 \pm 88^{*}$ & $\mathrm{ND}$ & $66 \pm 10^{*}$ & $183 \pm 34$ \\
LPS $100 \mathrm{ng} / \mathrm{ml}$ & $456 \pm 92^{*}$ & $4.55 \pm 2.04^{*}$ & $112 \pm 25$ & $124 \pm 30$ \\
(B) & & & & $172 \pm 41$ \\
Control & $355 \pm 116$ & $2.51 \pm 0.57$ & $161 \pm 22$ & $191 \pm 55$ \\
IFN $\gamma 100 \mathrm{U}$ & $302 \pm 109$ & $1.94 \pm 0.63$ & $114 \pm 32^{*}$ & $182 \pm 50$ \\
LPS $100 \mathrm{ng} / \mathrm{ml}$ & $418 \pm 111$ & $2.97 \pm 0.63$ & $77 \pm 13^{*}$ & \\
\hline
\end{tabular}

$N D$ not detectable

${ }^{*} \mathrm{p}<0.05$ LPS, IFN $\gamma$ versus control (Mann-Whitney U test) with IFN $\gamma$ and MPST activity after $24 \mathrm{~h}$ (Table 3A, B), the activity of which is regulated through a redox-switch regulatory mechanism [25]. However, higher expression of CTH after $48 \mathrm{~h}$, in comparison to $24 \mathrm{~h}$, resulted in an increased level of hydrogen sulfide (Figs. 1, 2a, b).
In case of LPS, a higher production of $\mathrm{H}_{2} \mathrm{~S}$ after $48 \mathrm{~h}$, as compare to $24 \mathrm{~h}$, is also correlated with higher increase in CTH expression after both IFN $\gamma$ and LPS stimulation. An increased expression of $\mathrm{CTH}$ and $\mathrm{H}_{2} \mathrm{~S}$ production in the macrophages stimulated with LPS was earlier reported 
[26]. A decreased expression and activity of MPST after $24 \mathrm{~h}$ (Fig. 2a, b; Table 3A) limits the amount of cysteine converted by this enzyme and make it more available for $\mathrm{H}_{2} \mathrm{~S}$-generating reactions catalyzed by CTH (Scheme 1). Interestingly, the expected increased level of HCys in J774A. 1 cells with low CBS expression and activity, is associated with a high $\mathrm{CTH}$ expression. A decreased level of $\mathrm{H}_{2} \mathrm{~S}$ after $24 \mathrm{~h}$ stimulation with both IFN $\gamma$ and LPS was also associated with an increased CTH expression. These observations may confirm the suggested effect of HCys (increased due to low CBS level) and $\mathrm{H}_{2} \mathrm{~S}$ on $\mathrm{CTH}$ expression, which is upregulated by high levels of HCys and low $\mathrm{H}_{2} \mathrm{~S}$ levels and a negative feedback regulation between CBS and CTH [8]. Increased HCys level together with the elevated level of CTH (IFN $\gamma, 48 \mathrm{~h}$ ) can result in cysteine sucking into reactions with HCys and its lower availability for GSH synthesis. Decreased GSH levels result in an increased level of reactive oxygen species which are, in turn, involved in the redox regulation of immune cells [27].

$\mathrm{H}_{2} \mathrm{~S}$ can be regarded an $\mathrm{O}_{2}^{--}$scavenger-it reacts with superoxide radical anion (Scheme 1). $\mathrm{H}_{2} \mathrm{~S}$ is a reducing agent and a weak acid with approximately $4: 1 \mathrm{HS}^{-} / \mathrm{H}_{2} \mathrm{~S}$ ratio at physiological $\mathrm{pH}$ [28]. $\mathrm{HS}^{-}$, as opposed to $\mathrm{H}_{2} \mathrm{~S}$, can reduce the metal center of cytochrome $\mathrm{c}$ and lead to production of $\mathrm{O}_{2}^{-}$from molecular oxygen [29]. On the other hand, $\mathrm{HS}^{-} / \mathrm{H}_{2} \mathrm{~S}$ can reduce $\mathrm{Cu}^{2+}$ to $\mathrm{Cu}^{1+}$ and enhance $\mathrm{O}_{2}^{--}$scavenging activity of the copper-zinc SOD (CuZnSOD) [29, 30]. Sulfide is a potent reversible inhibitor of myeloperoxidase activity [31]. It has also been shown that HCys can induce Trx-1 expression in human monocytes [32] and in this way potentiate the antioxidant protection of cells (Scheme 1). Thus, in cells, $\mathrm{H}_{2} \mathrm{~S}$ can act as a pro- or antioxidant, depending on the $\mathrm{H}_{2} \mathrm{~S}_{2} \mathrm{HS}^{-}$ratio.

In stimulated cells, hydrogen sulphide can react with nitric oxide [33], what can result in decreased $\mathrm{H}_{2} \mathrm{~S}$ levels, especially pronounced after $24 \mathrm{~h}$, and particularly in the IFN $\gamma$-stimulated cells with a massive amount of proinflammatory mediators released (Table 1). On the other hand, $\mathrm{H}_{2} \mathrm{~S}$ might also exert anti-inflammatory effects by inhibiting NO production [11]. $\mathrm{H}_{2} \mathrm{~S}$ oxidation results in persulfides and thiosulfate formation [34], substrates of mitochondrial rhodanese. It catalyzes the transfer of sulfane sulfur atom from thiosulfate to various acceptors (e.g. GSH), leading to $\mathrm{H}_{2} \mathrm{~S}$, and allows for recycling $\mathrm{H}_{2} \mathrm{~S}$ without consuming additional cysteine. However, it seems this does not occur due to its significantly decreased activity after $48 \mathrm{~h}$ stimulation with both IFN $\gamma$ and LPS (Table 3A, B). On the other hand, a homeostasis of sulfane sulfur level was observed (Table 3A, B).

\section{Conclusions}

J774A. 1 macrophage cells are hydrogen sulphide-producing cells with CTH as the main enzyme and MPST playing a supporting role. A low CBS expression and non-detectable CBS activity in the IFN $\gamma$-stimulated cells can result in HCys availability for $\mathrm{CTH}$-catalyzed, $\mathrm{H}_{2} \mathrm{~S}$-generating reactions (Scheme 1). A decreased level of $\mathrm{H}_{2} \mathrm{~S}$ after $24 \mathrm{~h}$ stimulation with both IFN $\gamma$ and LPS associated with an increased CTH expression can confirm CTH upregulation by a high level of $\mathrm{HCys}$ (due to low CBS expression) and low $\mathrm{H}_{2} \mathrm{~S}$ and a negative feedback regulation between $\mathrm{CBS}$ and $\mathrm{CTH}$.

Acknowledgements This work was supported by a Grant from the National Committee for Scientific Research K/DSC/003590 and K/ ZDS/007220.

Author contributions P.B.-A. provided the experimental data, analyzed the data, wrote the manuscript in consultation with M.W., P.S., A.G. provided the experimental data. H.J. performed and developed the RTPCR analysis, contributed to the interpretation of the results. K.N. supervised and performed cell cultures. J. M. and M.W. discussed the results and contributed to the final manuscript.

\section{Compliance with ethical standards}

Conflict of interest The authors declare no conflict of interest.

Open Access This article is distributed under the terms of the Creative Commons Attribution 4.0 International License (http://creativeco mmons.org/licenses/by/4.0/), which permits unrestricted use, distribution, and reproduction in any medium, provided you give appropriate credit to the original author(s) and the source, provide a link to the Creative Commons license, and indicate if changes were made.

\section{References}

1. Wang R (2002) Two's company, three's a crowd: Can $\mathrm{H}_{2} \mathrm{~S}$ be the third endogenous gaseous transmitter? FASEB J 16:1792-1798

2. Sen U, Mishra PK, Tyagi N, Tyagi SC (2010) Homocysteine to hydrogen sulfide or hypertension. Cell Biochem Biophys 57:49-58

3. Shibuya N, Tanaka M, Yoshida M, Ogasawara Y, Togawa T, Ishii K, Kimura H (2009) 3-Mercaptopyruvate sulfurtransferase produces hydrogen sulfide and bound sulfane sulfur in the brain. Antioxid Redox Signal 11:703-714

4. Mikami Y, Shibuya N, Kimura Y, Nagahara N, Ogasawara Y, Kimura H (2011) Thioredoxin and dihydrolipoic acid are required for 3-mercaptopyruvate sulfurtransferase to produce hydrogen sulfide. Biochem J 439:479-485

5. Bhatia M (2012) Role of hydrogen sulfide in the pathology of inflammation. Scientifica. https://doi.org/10.6064/2012/159680

6. Li M, Whiteman L, Rose P, Tan CH, Parkinson DB, Moore PK (2010) The effect of hydrogen sulfide donors on lipopolysaccharide-induced formation of inflammatory mediators in macrophages. Antioxid Redox Signal 12:1147-1154

7. Kartha RV, Zhou J, Hovde LB, Belinda WY, Cheung BWY, Schröder H (2012) Enhanced detection of hydrogen sulfide 
generated in cell culture using an agar trap method. Anal Biochem 423:102-108

8. Nandi SS, Mishra PK (2017) $\mathrm{H}_{2} \mathrm{~S}$ and homocysteine control a novel feedback regulation of cystathionine beta synthase and cystathionine gamma lyase in cardiomyocytes. Sci Rep 7(1): 3639

9. Jurkowska H, Placha W, Nagahara N, Wróbel M (2011) The expression and activity of cystathionine- $\gamma$-lyase and 3-mercaptopyruvate sulfurtransferase in human neoplastic cell lines. Amino Acids 41:151-158

10. Brunner M, Gruber M, Schmid D, Baran H, Moeslinger T (2015) Proliferation of macrophages due to the inhibition of inducible nitric oxide synthesis by oxidized low-density lipoproteins. EXCLI J 14:439-451

11. Oh GS, Pae HO, Lee BS, Kim BN, Kim JM, Kim HR, Jeon SB, Jeon WK, Chae HJ, Chung HT (2006) Hydrogen sulfide inhibits nitric oxide production and nuclear factor-kappaB via heme oxygenase-1 expression in RAW264.7 macrophages stimulated with lipopolysaccharide. Free Radic Biol Med 41:106-119

12. Shanmugam MK, Jing Z, Bhatia M (2009) Aminooxyacetate inhibits hydrogen sulfide and ammonium synthesis and protects mice in acute pancreatitis. Int J Integr Biol 8:7-14

13. Valentine WN, Frankelfeld JK (1974) 3-Mercaptopyruvate sulfurtransferase (EC 2.8.1.2): a simple assay adapted to human blood cells. Clin Chim Acta 14:05-210

14. Wróbel M, Jurkowska H, Śliwa L, Srebro Z (2004) Sulfurtransferases and cyanide detoxification in mouse liver, kidney, and brain. Toxicol Mech Methods 14:331-337

15. Bronowicka-Adamska P, Wróbel M, Magierowski M, Magierowska K, Kwiecień S, Brzozowski T (2017) Hydrogen sulphide production in healthy and ulcerated gastric mucosa of rats. Molecules 22:1-13

16. Matsuo Y, Greenberg DM (1958) A crystalline enzyme that cleaves homoserine and cystathionine. J Biol Chem 230:545-560

17. Czubak J, Wróbel M, Jurkowska H (2002) Cystathionine $\gamma$-lyase (EC 4.4.1.1): an enzymatic assay of $\alpha$-ketobutyrate using lactate dehydrogenase. Acta Biol Cracov Ser Zool 44:113-117

18. Bronowicka-Adamska P, Wróbel M, Zagajewski J (2015) An application of RP-HPLC for P determination of the activity of cystathionine beta-synthase and gamma-cystathionase in tissue homogenates. Nitric Oxide 46:186-191

19. Bronowicka-Adamska P, Wróbel M, Zagajewski J (2011) RPHPLC method for quantitative determination of cystathionine, cysteine and glutathione: an application for the study of the metabolism of cysteine in human brain. J Chromatogr B 879:2005-2009

20. Wood L (1987) Sulfane sulfur. Methods Enzymol 143:25-29

21. Lowry OH, Rosenbrough NJ, Farr AL, Randall RI (1951) Protein measurement with the Folin phenol reagent. J Biol Chem 193:265-275

22. Dominik PK, Cassidy PB, Roberts JC (2001) A new and versatile method for determination of thiolamines of biological importance. J Chromatogr B 761:1-12
23. Olson KR (2012) A practical look at the chemistry and biology of hydrogen sulfide. Antioxid Redox Signal 17:32-44

24. Prathapasinghe GA, Siow YL, Xu ZOK (2008) Inhibition of cystathionine-synthase activity during renal ischemia-reperfusion: role of $\mathrm{pH}$ and nitric oxide. Am J Physiol Ren Physiol 295:F912-F922

25. Nagahara N (2013) Regulation of mercaptopyruvate sulfurtransferase activity via intrasubunit and intersubunit redox-sensing switches. Antioxid Redox Signal 19:1792-1802

26. Zheng Y, Luo YN, Mu D, Jiang P, Liu R, Sun H, Xiong S, Liu X, Wang L, Chu Y (2013) Lipopolysaccharide regulates biosynthesis of cystathionine $\gamma$-lyase and hydrogen sulfide through toll-like receptor-4/p38 and toll-like receptor-4/NF- $\mathrm{\kappa B}$ pathways in macrophages. In Vitro Cell Dev Biol Anim 49:679-688

27. Miljkovic D, Spasojevic I (2013) Multiple sclerosis: molecular mechanisms and therapeutic opportunities. Antioxid Redox Signal 19:2286-2334

28. Mijušković A, Oreščanin-Dušić Z, Nikolić-Kokić A, Slavić M, Spasić MB, Spasojević I, Blagojević D (2014) Comparison of the effects of methanethiol and sodium sulphide on uterine contractile activity. Pharmacol Rep 66:373-379

29. Bolić B, Mijušković A, Popović-Bijelić A, Nikolić-Kokić A, Spasić S, Blagojević D, Spasić MB, Spasojević I (2015) Reactions of superoxide dismutases with $\mathrm{HS}^{(-)} / \mathrm{H}_{2} \mathrm{~S}$ and superoxide radical anion: an in vitro EPR study. Nitric Oxide 51:19-23

30. Searcy DG, Whitehead JP, Maroney MJ (1995) Interaction of Cu, $\mathrm{Zn}$ superoxide dismutase with hydrogen sulfide. Arch Biochem Biophys 318:251-263

31. Pálinkás Z, Furtmüller PG, Nagy A, Jakopitsch C, Pirker KF, Magierowski M, Jasnos K, Wallace JL, Obinger C, Nagy P (2015) Interactions of hydrogen sulfide with myeloperoxidase. Br J Pharmacol 172:1516-1532

32. Dai J, Wang X, Feng J, Kong W, Xu Q, Shen X, Wang X (2008) Regulatory role of thioredoxin in homocysteine-induced monocyte chemoattractant protein-1 secretion in monocytes/macrophages. FEBS Lett 582:3893-3898

33. Nagpure BV, Bian JS (2016) Interaction of hydrogen sulfide with nitric oxide in the cardiovascular system. Oxidative Med Cell Longev 2016:1-16

34. Libiad M, Yadav PK, Vitvitsky V, Martinov M, Banerjee R (2014) Organization of the human mitochondrial $\mathrm{H}_{2} \mathrm{~S}$ oxidation pathway. J Biol Chem 289:30901-30910

Publisher's Note Springer Nature remains neutral with regard to jurisdictional claims in published maps and institutional affiliations. 